\title{
TRANSLATING DIGITAL LITERATURE: TWO EXPERIENCES AND A REFLECTION
}

\author{
Giovanna di Rosario* \\ Laura Borràs*
}

\begin{abstract}
In this article we would like to talk about our experience in translating digital poetry. In a text there are always elements that seem to be/are untranslatable. There will always be a certain degree of loss in meaning when a text is translated, but what does it mean to translate Electronic Literature? Electronic Literature is a transnational (thus translingual), interdisciplinary, and multimodal practice. Electronic literature creates a text which is unstable; a text that can change its form and its content. The electronic text is causing a true reconfiguration of the literary creation, how can/should we translate a text that is unstable by its nature, that moves, changes and interacts with other semiotic systems? Though we are still at the beginning of this new discipline, nowadays, there are some examples of translation of e-literature: for instance the Finnish website nokturno.org provides translations into several languages of electronic literature. But what do we need to translate, to transfer into another language and into another culture, when we are translating electronic literature? What happens, for instance, to the aesthetic effects created by moving letters and their meaning when these words are translated to another languages whose structure could be very different from the departing language. How does one describe the intralingual and the intersemiotic translation process in e-literature? And how are different semiotic systems related to each other in an intersemiotic translation?
\end{abstract}

KEY WORDS: Electronic literature. Translation studies. Intralingual and intersemiotic translation. New discipline.

In this article we would like to talk about our experience in translating digital poetry. The article is structured in three parts. In the first part we would like to think and rethink about translation, both as a process and as a product of this process. We will approach the act of translating from a semiotic and translation theory point of view, trying to offer our reader an interface between these two areas of research. The second part will focus on translating digital poetry. We will first summarize some of the characteristics of digital literature in order to understand what new difficulties the translator may face to in translating this new form of literature. Finally, we will deal with our practical experiences in translating digital poetry.

\footnotetext{
*Universitat de Barcelona / Hermeneia Research Group. giodiros@gmail.com

*Universitat de Barcelona / Hermeneia Research Group. lborrasc@gmail.com
} 
The verb "to translate" derives from Latin translatus - past participle of transferre (to transfer), from trans + latus - latus being the past participle of ferre (to carry). According to the Oxford English Dictionary the verb "to translate" has 4 meanings":

1. express the sense of (words or text) in another language;

2. (translate something into/translate into) convert something or be converted into (another form or medium);

3. move from one place or condition to another:

4. Physics cause (a body) to move so that all its parts travel in the same direction, without rotation or change of shape.

The term translation, thus, leads to notions of expressing or converting one word, phrase, or text to another, of transferring or moving from one place to another while maintaining meaning.

In his famous essay "On Linguistic Aspects of Translation"2 Roman Jakobson highlighted three types of translation (namely intralingual, interlingual and intersemiotic) opening up questions that go beyond the linguistic domain by virtue of including nonverbal signs.

According to William Frawley, translation is a reconfiguration. "[T]ranslation is the bilateral accommodation of a matrix and a target code [...] the translation itself [...] is essentially a third code which arises out of the bilateral consideration of a matrix and a target code: it is in a sense a subcode of each of the codes involved" (1984, p. 167). Thus the translation is a new code with new information.

It is not our intention to make a theoretical discourse on translation, or much less follow the results from the historical and theoretical studies that have been built in the last decade, but we think it is important to highlight some fundamental aspects of it in order to approach the process of translation in digital literature.

\footnotetext{
1 Oxford Online Dictionary. Available in: $<$ http://oxforddictionaries.com/definition/translate?q=translate $>$. Access in: March 1, 2012). 2 JAKOBSON, R. On Linguistic Aspects of Translation. In: BROWER, R. (Ed.). On Translation. Oxford: Oxford University Press, 1959. p. 232-239.
} 
The translation process can be seen both as an adaptation and as a creation, as a rewriting of the reference text, since translation is one of the ways in which literature is rewritten. The result of this complexity has caused in the last two decades the rise to preeminence of Translation Studies such that they have become one of the central disciplines of the "humanities". The role of the translator is crucial for many reasons, but the most interesting task to us is the role of translation as a form of textual interpretation. Feminist critique, post-structuralism and the theory of deconstruction have led us to see and read in the text produced by translation an other text with respect to the original text: a recreated text and not "merely" a translated text, but a différent text (Derrida). Every language involves a deep look at the world it represents. Every language is a way to think about and thus represent a particular world for every culture. Through language we all inherit a particular conception of the world. Therefore the translation act represents a transaction not only on a linguistic level, but with a cultural magnitude. Translating is a sensitive activity while at the same time voracious, where it takes place the anthropophagy or textual cannibalism that it means to feed on other people's texts to generate our own, but also the act of giving birth, of creating, of inventing (in its etymological meaning from the Latin invenire). Somehow we could see the translators as cannibals who devour and assimilate foreign texts in order to provide the result of their "textual chewing".

According to Itamar Even-Zohar every community needs a successful cultural planning through the construction of a repertoire of objects, models and laws to survive. Naturally, in that repertoire the texts we receive (via translation) from other cultures play crucial roles. These texts are somehow "manipulated" to meet the needs of the host community. From this point of view, the translations (whether literary or non-literary) is an interesting phenomenon as a socio-semiotic study, which can offer valuable items for trial research about social institutions.

It is a knowledge that works in the intersections between translated texts and ideology. The ultimate goal would be to determine the role that ideological translations can play in the most varied cultural situations. The exercise of 
translation goes beyond a purely linguistic conception and represents something more than a "transferred" language.

Eugene Nida, among others, remarks that language does not consist solely of meanings of symbols, and the combination of symbols. Semiotically language is a code. This code operates with a specific purpose. Again Nida underlines the importance of analyzing the transmission of a message in terms of a "dynamic dimension", which is even more important when dealing with translation. According to him "[t]he production of equivalent messages is a process, not merely of matching parts of utterances, but also of reproducing the total dynamic character of the communication. Without both elements the result can scarcely be regarded in any realistic sense, as equivalent" (1964, p. 120).

Translating words also means translating a culture and an experience through a textual form. 'Translating' always connects two cultures and adds to the departed text ingredients from the culture of arrival regardless of the "visibility" or "invisibility" of the translator. As pointed out by Venuti, every translation is a rewriting of a foreign original following the cultural values of the host community. From here on there are two ways to deal with translation in a humanist way, a process where the translator is invisible and the intended objective is a certain domestication of the translated text, and a process that happens in the manner of "otherness", a way that provides historical information about when was the text translated and where the translator is a visible presence (VENUTI, 1995, n/p).

Translation is always a hybrid cultural product in construction and conflict. The activity of cross-cultural representation that lies always in the background behind any act of translation is an issue of utmost interest. The act of translating is deeply linked to the question of cultural identity, difference and similarity. Translation is not a neutral activity. No translations are innocent. In one way or another, the person who translates, consciously or unconsciously, leaves their mark on the text. In this sense, this process is even more complex when you start from a situation of cultural otherness that has to be added to the linguistic one. But in 
Digital Literature the otherness is represented, of course, by the code too, by the programming language.

\title{
The Visible Translators: Translating Digital Poetry
}

One interesting approach to literary translation is offered by Michel Riffaterre. He divides the use of language into literary and non-literary cases. He says that

\begin{abstract}
Literary translation is different from translation in general for the same reason that literature is different from non-literary use of language. Literature is distinguished from them first by the semiotizacion of the discursive features (for instance, lexical selection is made morphophonemically as well as or more than semantically). Second by substitution of semiosis for mimesis [...] And third by 'textuality' that integrates semantic components of the verbal sequence (the ones accessible to linear decoding) - a theoretically open-ended sequence-into one closed, finite semiotic system [...](1992, p. 204).
\end{abstract}

According to him, the literary translation should "reflect or imitate these differences". Gideon Toury states that "translation, and especially literary translation, involves at least two languages and two cultural traditions, i.e., at least two sets of norm-systems [...]". But what happens to literary translation when it moves into digital? Are there other further ways in which translating digital literary works is a problematic endeavor?

Digital literature consists of digital artifacts written for the digital medium. These texts should have certain structural and/or operative forms not readily reproducible in paper or in any non-digital medium. These include employing hyperlinks, kinetic elements, programmable elements (GLAZIER, 2002, p. 163). The term "digital literature" encompasses a wide range of practices which are difficult to sum up. In order to do so let us focus on the text and on its relationship with the author and the reader:

1) concerning the text: the different mediums chosen to "write/read" the digital literature on/from: installations and video-installations, texts created to be 
read on the desktop or the laptop screen ${ }^{3}$ - or nowadays also on smartphones and tablets, and performances;

2) concerning the text and the author: generative poetry or computer poetry programmed by the author and generated by the machine and electronic poetry which is not generative (which largely appears to constitute the bulk of the works created);

3) concerning the "nature" of the text and its relationship with the reader: animated/kinetic poetry, hypertexts, interactive texts ${ }^{4}$.

This distinction is not merely a distinction of "forms", it is not making a distinction between translating prose or poetry, and so on (with all the problematic it will imply). When talking about translating digital literature, other aspects (that simply do not exist in printed literature) need to be taken into consideration. Translating a piece of electronic literature thought to be "read" as an installation presents different challenges from translating a hypertext or a digital text with images and sounds.

Moreover, according to many scholars translating poetry poses more difficult issues than translating prose. This is due because poetry stresses more the musical quality of language while prose emphasizes more the meaning. $R$. Jakobson, for instance, believes that translating poetry is "by definition impossible $[\ldots]$ only creative transposition is possible [...]".

The difficulty of translating a poetic work probably represents the maximum degree of difficulty when facing translation activities. Recently, in the MA in Literature where I am the Academic Director, we were working on Digital Poetry and I proposed that the students should translate a digital poem. I figured out that this could be the way to deeply penetrate into the meaning of the text, but also in the

\footnotetext{
${ }^{3}$ Those texts can be on floppy disk, CD, DVD or accessible online. The very first e-poems were created on floppy and nowadays they are not easily readable anymore. The problem of how to preserve and archive electronic literature is a serious one. Some projects that are on-going are trying to archive e-literature even though some texts will be most probably lost forever.

${ }^{4}$ Cf. DI ROSARIO, G. Electronic Poetry. Understanding Poetry in the Digital Environment, Jyväskylä: Jyväskylä University Press, 2011.
} 
case of Digital Literature, to understand the dual nature of a digital text, its virtual materiality. I would like to share here a small but significant part of the process.

\section{Migrating discourses: an example from digital poetry by Laura Borràs}

The poem we were dealing with is this small piece of digital poetry by the American author, Deena Larsen titled "I'm simply saying" despite the fact that the title of the poem that appears in the browser toolbar when searching for it, and therefore how many people just refer to it, is Simply7. It is an interactive poem, programmed with Flash text, images and music, but with a logic that relies on the act of reading. A poem, then, that contains many poems inside itself, based on the multiple reading possibilities that its navigation and deployment allows.

The project got under way with a lot of interest and there began the process of translation into Catalan and Spanish, because there were Latin American students enrolled in the program, and immediately a horizon of doubts came into view ${ }^{5}$. What happens with the text that appears and disappears, making "mischief" (as was expressed by Oreto Domènech on 20 May 2008)? They had to fix onto it first in order to "possess" all the words, to read it all:

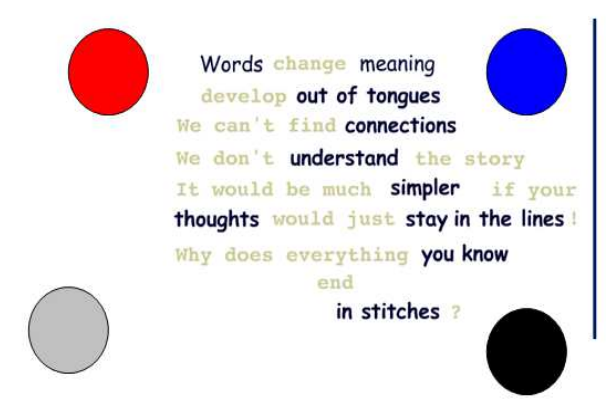

Fig. 1: Deena Larsen, I'm simply saying

$\begin{array}{ll}\text { Words change meaning } \\ \text { Poems } & \begin{array}{l}\text { relationships } \\ \text { Seams }\end{array} \\ \text { relations } \\ \text { Patterns } & \begin{array}{r}\text { revelations } \\ \text { Memories }\end{array} \\ \text { Times } & \text { reveal intentions }\end{array}$

\footnotetext{
${ }^{5}$ The translation process was done by O. Doménech, S. Hurtado, B. Rubio, A. Grabolosa, LI. Vila, J. Turon, R. Olvera, R Castañeda, C. Vilardebo, J. Cercós, C. Casals, J. Ribera, J. Adell \& L. Borràs.
} 
develop out of tongues

out of range

out of view

off tangents

off targets

out of our lives

We can't find connections

protections

projections

projectures

conjectures

We don't understand the story

underscore

undermine

uncover

recover

restore

It would be much simpler if your

thoughts would just stay in the lines!

notations

stay still (in the lines)

notions

stop breaking (in the lines)

commotions

stop faking (in the lines)

emotions

start unpacking (in the lines)

(motions)

start packing (in the lines) 
Why does everything you know

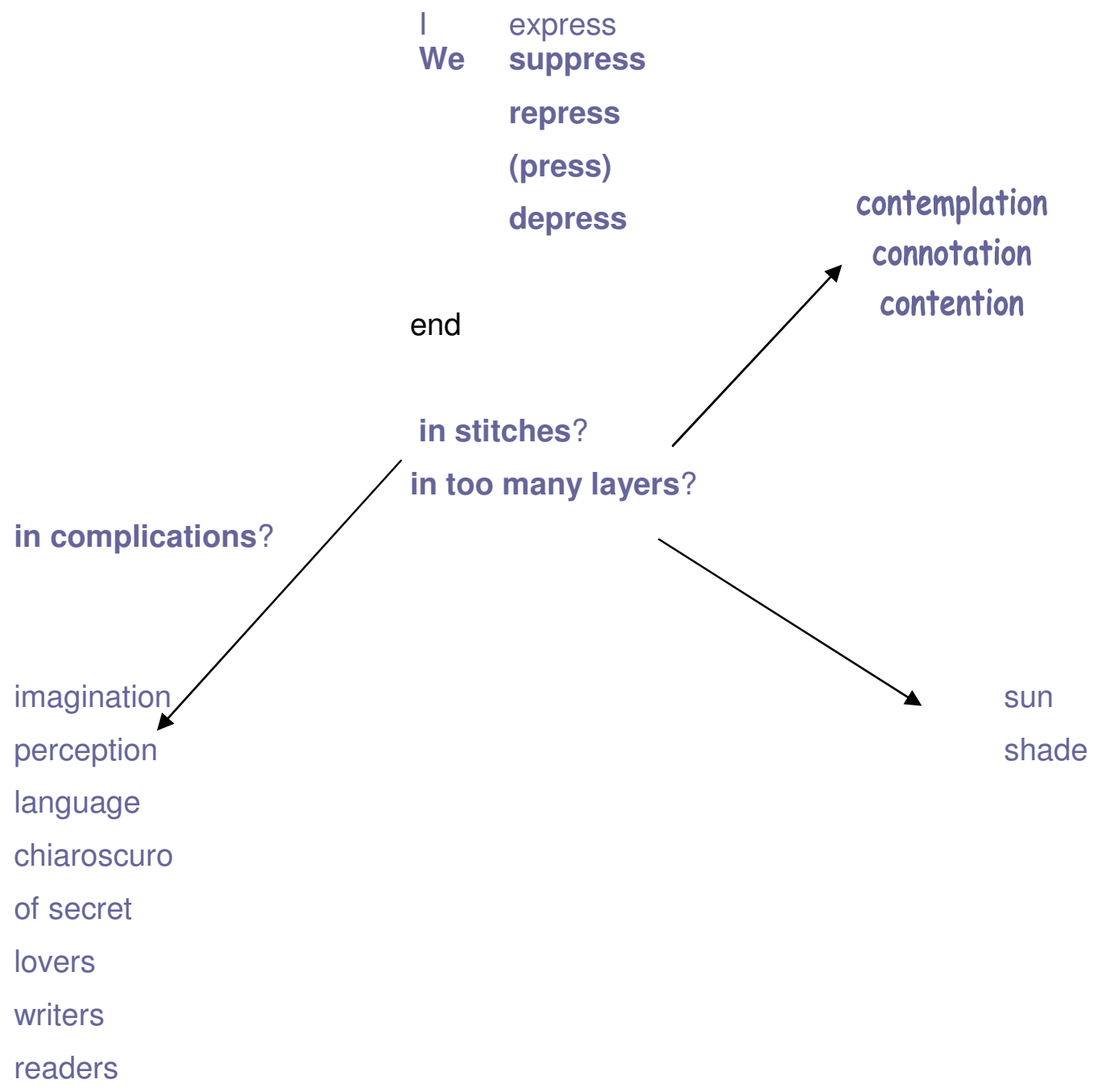

suicide 


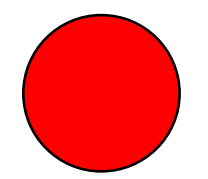

What else is secret

sacred

safe love and death?

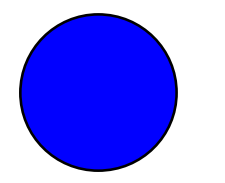

code

symbol

intent

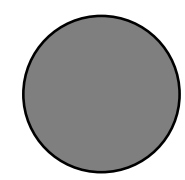

The secret

Does not lie

In Bluebeard's closet. $\rightarrow$ but flies free

Secrets lie

in lily cool faces

in rose warm blood

in orchid dry bruises

punctured by

realities

of fast cars

and faster modems 


\section{SIMPLER}

You stand and watch while the story boils down to its bones.

Writer meets secret.

Reader

Writer loves secret.

Reader

Secret leaves writer for

the hero with the fast

red Lamborghini.

Writer uses secret's bones

Reader

to dig a predetermined grave.

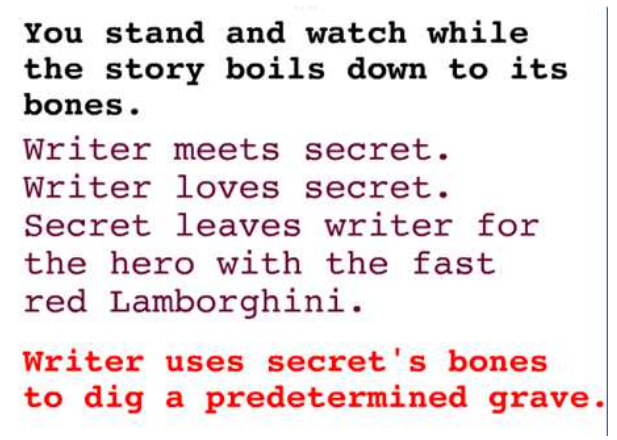

Fig. 2: Deena Larsen, I'm simply saying

Here are some of the moments that took place in this process of collective bilingual online translation.

\section{About the title:}

Berta Rubio (15/05/2008)

\section{Hello!}

I like Josep's version and his small modifications to Laura's translation.

On the one hand, the inclusion of the pronoun subject in Catalan, I believe, gives emphasis unnecessary (in English it is mandatory, of course) and the phrase "I'm simply saying" seems much more simple and appropriate with everything we said about the poem, which gives an "obvious indication" that it is very good.

For the same reason I also like the elimination of "that".

Regarding the translation of kicks, it is also wise to keep the semantic field of sewing resumed in the "off": seams (seams, joints), patterns (patterns, designs or patterns but also prints, etc.). In any case, there are a number of double meanings that we inevitably lose, but perhaps we can find new ones!

There is another verse that seems more or less problematic "beyond language." In Catalan the word "language" has a double meaning: bodily (muscle, tongue) and language spoken by the "tongue" ... I do not understand too much the game in the English line, can somebody help me? 
In line 6 "(if your) Thoughts would just stay in the line," don't you think that it will be much more strong to keep this idea of "fair"? Do you already consider that in the Catalan and Spanish translation it is reflected within "keep"?

If you ask me to choose between "is maintained" and "being" (still in verse 6), I have not quite decided between "deployed" or "develop" - I could decide by myself, but perhaps I see more semantic game to "unfold" ... probably because the format of the poem suggests to me this idea down in words ... What do you think?

There is another thing that bothers me ... who is the subject of "end"? If "everything you know" (3rd person. Singular), should not end in "s" (ends)? (...)

\section{Oreto Domènech (05/15/2008)}

Hello again!

Oh that is really thrilling!

About what you say, Berta, the bodily of language ... To "unfold (leave / leaving) the language" may remain this way.

But perhaps there is little poetry inside...

I do have many questions... Professional translators: I admire you!

Oreto.

$$
\text { Berta Rubio (15/05/2008) }
$$

(...) It's fantastic ... but I agree with the fact that the translation is getting increasingly complicated

(...) I do not think that the problem is whether or not we can take the license to translate the original poem into a more or less literal sense, but depending on what we choose, we amend our choice for all subsequent translations, of the changing words of the lines, I mean ... Wow, it is difficult! (...)

\section{Cristina Casals $(05 / 15 / 2008)$}

Oh my goodness!

It is fascinating to return home from work and to see this forum so packed I am overwhelmed by all your contributions... but, anyway, I took the poem with me on the bus and l've been working on it. Regarding the title: as Jaume says it works very well but lost. I opted for just trying to keep the English "Present Continuous" to emphasize it: "I'm simply saying" indicating "I ONLY say that...". Regarding the word STORY: I do not know exactly how to do it, but I also think that we should try to separate the HISTORY that is linked with our history, however, story, story ... not so pretty. In line 6, I think we should try to highlight the word FAIR. That evokes in me (what about you?) an unsettling reaction: I don't know whether desperate or disturbing, but intense and emotionally full of instant adventure... I also thought about EXACTLY... but it doesn't sound too poetic ...

Regarding LINES: I prefer to have them translated as "lines" instead of verses... I think this universalizes the poem and opens it to any line (poetic or not), the way as Deena does it, in choosing LINES instead of VERSES.

Finally, related to "STITCHES" ... it is driving me crazy... if we talk about sewing then we normally use stitches, but to use KICK would seem like if the poem ended with a "kick" in the ass ... forgive me for the association ...

Well ... these are my attempts of the initial translation that Laura and Josep have proposed.

I'll keep reading you!

A big hug!

Cristina

Oreto Domenech (05/15/2008)

The same thing happens to me, Cristina, I have a smile on my lips and it has not faded since last night! Berta, (...) regarding the translation of "kicks," I also think it's wise to keep the semantic field of sewing like this:

Texto Digital, Florianópolis, v. 8, n. 1, p. 138-162, jan./jul. 2012. ISSNe: 1807-9288 
As for "off": seams (seams, joints), patterns (Patterns, designs or patterns but also prints, etc.). I have a question (...) What is more important when translating poetry: to try to hold as much as possible the words from the original text or to create, as much as possible, a translated text similar to the sense of the original? Words or sense?

Oreto.

$$
\text { Berta Rubio (15/05/2008) }
$$

Every time I read your comments I realize and learn more and more things!

A note on the subject "lines"... Cristina! I had not even noticed! I also opted for lines since it sounds like evoking a more playful connotation, right? "Stay in the line" sounds a little too colloquial. I tried to check it, is it? I know that "to be in-line" means "being under" and I found "stay in the line" in a couple of songs and I guess that with the sense to keep the limit at the threshold, the line at the end ... I do not know if I'm just making it up ...

Wow, l'm enjoying it a lot!!!

Carla Vilardebó (05/15/2008)

Berta I understand that the "stay in line" works more like a warning (about not going to the limit), given the imperative of the sentence (marked by the lack of the subject), and especially if we think "to keep (as a synonym of stay or remain) something or somebody in line" means to keep someone at bay with discipline.

Furthermore ... line also refers to an area, field or specialty. And if the words change the meaning ... perhaps it is beyond the scope of the word, beyond discipline ...

I think it starts getting delirious but I love it and I learn a lot!

Good night!

Carla.

This is just a sample of "brain storming." But then, every word, every nuance generates debate and contributions and reflections on a cultural, linguistic, aesthetic and ethical level.

Jaume Ribera (05/16/2008)

Here I come with "kicking" again. It was good that we reflected on the term and went back to sewing. None of you talked about this, but the weaving process can also be related to Penelope, to full of pain as well.

In late May 2008 I met Deena Larsen at an ELO (Electronic Literature Organisation) conference in Vancouver and there I explained to her what we were doing with her poem. She was immediately excited to hear about all the different thoughts, comments and linguistic nuances. She said she had been offered a picture of her poem that she knew someone had discovered through the mirror of another language and another reader, contributing with new meanings, images that were only suspected in the creation process. I even mentioned one of the questions we had, which was about the 7 in the title: we did not know what he meant in English and so we suggested to use in Catalan (because of the homonymy with English phonetics) "said", such as a possible translation: "Just Say" or "simply said ".

Laura Borràs (06/05/2008)

Hello! (...)

Let's see, I have two answers:

1) stitches.

Deena says she was referring to kicking, that is to say a kind of surgical emerged, although the thought of pain makes us laugh when we also put it together, such as a "plan".

So the question is imposed seamstresses.

2) Simply 7

It is really odd how things can turn out. It says that it is a pure coincidence that the poem appeared with the caption "SIMPLY 7": 7 appeared in the title because it was the latest version she worked with while saving the document. The thing is that she did not make a mistake and there was no mistake in the most widespread versions. Anyway, knowing that in Catalan, "SIMPLY 7" sounded

Texto Digital, Florianópolis, v. 8, n. 1, p. 138-162, jan./jul. 2012. ISSNe: 1807-9288 
such a phonetic trans-linguistic transcription: [simpli set] as "said" in English, I was amazed! So, you see. Strange things can happen, one day. Little did she imagine that her poem would be translated into Catalan and Spanish by brave students such as you?

Kisses,

Laura

Josep Turon (05/06/2008)

Welcome home Laura and Joan! Waiting to learn about your American experience! I cannot stop smiling when I read the comment of Deena and the origin of the title of the poem instead of the Catalan phonetic coincidence, because it could have taken centuries trying to figure out why Simply 7 . Here we can say that the machine got involved in the creation even in an involuntarily way, can't we...?

A hug and see you soon!

Josep

Berta Rubio (06/06/2008)

Ha, ha, ha! It's true! I still remember how, a few weeks ago, I was looking for seven different meanings for each word, instead of the 5-6 that each has!

Assumpta Grabolosa (06/07/2008)

Hello everyone. Very good, very good ... Sometimes things have unbelievable explanations ... But in the end, it was much more "simple" than we thought ...

See you soon,

Assumpta

Finally, Deena Larsen gave me the code, the other text, the hidden text that is necessary for the digital poem to be a reality, allowing to introduce the English digital poetry to Spanish and Catalan-speaking public. This is the result in Spanish: 


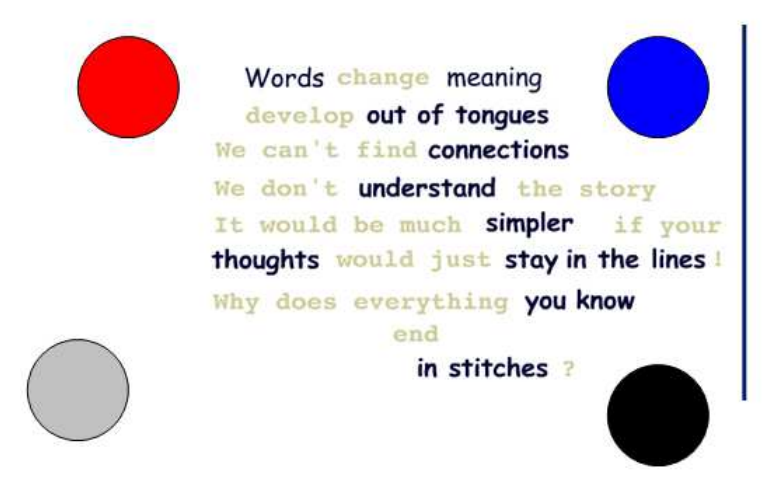

Figure 3 Deena Larsen, I'm simply saying

\title{
Simplemente digo
}

\author{
Las palabras cambian de significado \\ Poemas \\ Costuras \\ Patrones \\ Memorias \\ Tiempos \\ conexiones (aquí queda debatir lo de \\ relaciones los finales iguales por el \\ revelaciones tema de la animación \\ revelar intenciones flash)
}

Trasciende(n) las lenguas (yo lo prefiero al "van más allá" pero todavía queda aquello que apuntaba Luis Rodrigo del matiz de "favorecer". En cualquier caso si optamos por el "van más allá de", en los desplegables podríamos dejar "más allá de...")

Trasciende las posibilidades (A mí nada de esto me Trasciende el punto de vista convence del todo, he buscado fuera del punto de fuga sobre todo expresiones fuera del punto de mira que fueran fácilmente convertibles trasciende nuestras vidas en la animación. ¿Qué os parece a los que sabéis inglés?)

\section{No podemos encontrar conexiones}

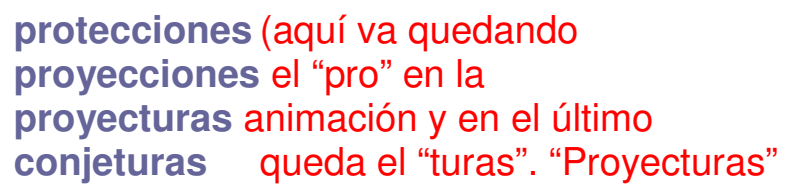

tiene una acepción en el ámbito de la arquitectura o del diseño... ¿qué os parece?)

No podemos entender la historia

Enfatizar (lo mismo, intentando dejar segmentos

Enflaquecer comunes entre las palabras)

Descubrir

Recubrir

Restablecer

¡Sería mucho más simple si tus

Pensamientos permanecieran dentro de las líneas!

"Se ocultaran" casará peor con el resto de desplegables

Anotaciones

Nociones sin moverse

sin romper 
Conmociones

Emociones

(locomociones)

Por qué todo lo que sabes

Exprimes (me ha hecho gracia la $4^{a}$

surpress

reprimes

(imprimes)

deprimes

acepción del DRAE: Expresar,.

manifestar)

sin deshacer

sin hacer imaginación percepción lenguaje termina

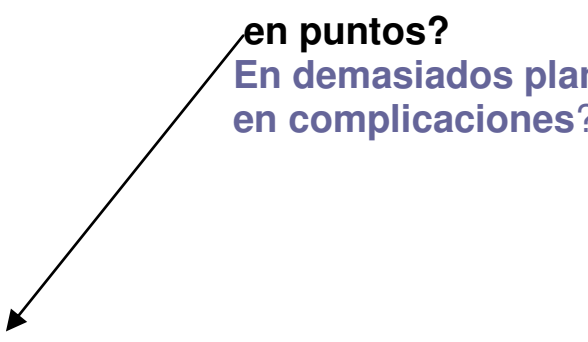

suicidio

Que más es secreto

sagrado

salvo el amor y la muerte?

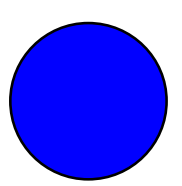

código

símbolo

intento

intriga

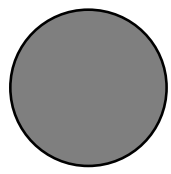

el secreto

no reposa (mejor, ¿no?)

en el armario de Barba azul $\rightarrow$ (sino que) vuela libre

Secrets lie El secreto se halla

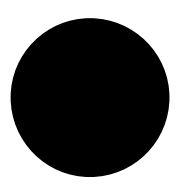

En frescos pétalos de lirios

(a lo Ramón

En la cálida sangre de la rosa Jiménez)

En la herida seca de la orquídea

Atravesada por

realidades

de coches rápidos

y aún más rápidos módems 


\section{Más fácil}

Te detienes y observas mientras

La historia se reduce hasta sus

huesos.

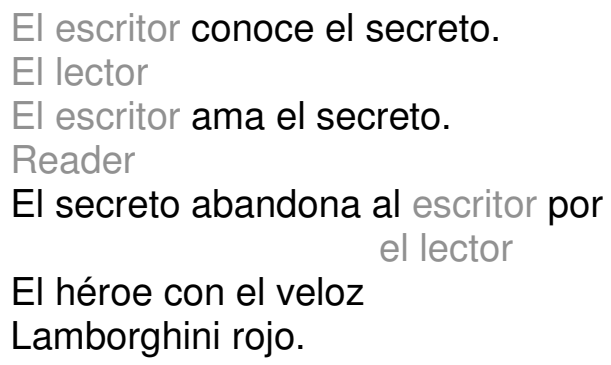

In Catalan, the final version of the translated poem was implemented in Flash by Berta Rubio and Isaías Herrero, student and teacher of the Master on Digital Literature of the University of Barcelona and can be seen here: $<$ <http://www.elevenkosmos.net/tallerFlash/senzill33/>.

The experience was fascinating and in fact we repeated the experience working on Amor de Clarice by Rui Torres, which we partially translated into Catalan. An early version online can be seen at: $<$ http://www.elevenkosmos.net/tallerFlash/amor2/>. Anyway, here the challenge was not only the linguistic translation and the code as a way of "creating" the work of e-lit, but the work we had to do with images, with the way of translating the text and the digital enhancement that the digital text conceived by Rui Torres on the text of Clarice Lispector had as an added value. The experience was innovative for as in the Master Program because we worked on small groups of four, not with the whole class as in Deena's translation. That provided us with a range variety of 
creativity since the exercise of translating the text had to go hand with hand with the creative process of imagining how to transfer the linguistic potential and meaning towards the image and the animation, made digital.

\section{From French into Italian by Giovanna di Rosario}

English appears to be the language of digital literature. This is due to many reasons: English is the international language, the Electronic Literature Organization is based in the U.S. the U.S. have a long tradition in developing Digital Literature, and so on. However, other countries have a tradition in Electronic Literature and especially as far as Europe is concerned it seems to be very important to translate Electronic Literature in order to make this more familiar with a broader audience.

In 2011 I co-organized in Naples the first Italian conference and exhibition of electronic literature. Several works were exhibited at the Palazzo delle Arti di Napoli - PAN Museum - for one month. The idea was to introduce digital literature to the Italian public and especially to people living in the South of Italy, that because of socio-cultural and historic reasons have always had less opportunities to encounter new artistic and cultural movements.

With a couple of colleagues we decided to translate their works from French into Italian: Alexandra Saemmer's Etang and Serge Bouchardon's Déprise.

The interactive and multimedia work Etang (Pond, $<$ http://www.mandelbrot.fr/Etang.html $>$ ) is the result of a writing experience Alexandra Saemmer had with a friend. Just like Saemmer's father, hers had died from a serious illness. For several weeks, they would meet and talk about their experience. Through short texts revolving around several themes, they would try to imagine each other's experience. These texts have been published in the journal lieu-dit 19 and inspired an animated, though not interactive, work on Mandelbrot's website, which has since been removed and destroyed by the authors 
In this text I will only focus on the problems caused by the animation of the words, which give the two texts different nuances of meaning. I will not analyse the difficulties encountered in translating the text, which refer to canonical linguistic problems of translating a text. At that time I was in Italy without a fast internet connection, so I could not see the text in its whole, I just had a PDF with Saemmer's Etang.

The text is composed of pictures (taken from a burned house), sound, and animated text. The text animations, though not so numerous, were particularly interesting and difficult to be "translated" into Italian.

Let us start with the animation that did not create any problems. The first one appears immediately on the text it is "les feuilles mortes" and these words seem to close up one another, according to Alexandra Saemmer, as if we are closing a book. This animation works in Italian as well.
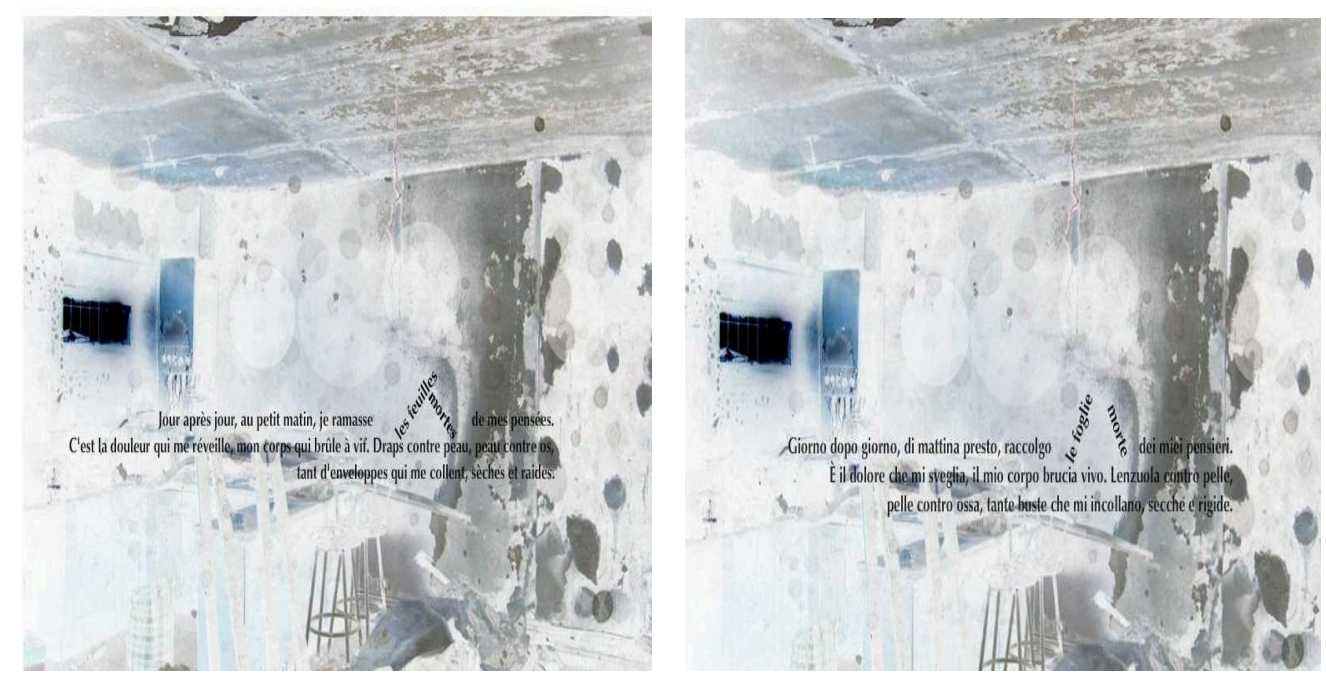

Fig. 4 and Fig. 5: Alexandra Saemmer, Etang - French and Italian version

Another animation that worked well in both languages is the verb "respirez" which in Italian is "respira". In this case too, the same animation was possible: both verbs break into pieces on the screen. According to Alexandra Saemmer, this animation should anticipate the end of the text, it should anticipate the implied "expirer"; as I 
said it works in Italian as well, moreover the same implied meaning is recognizable since in Italian "expirer" (to breathe out/to breathe one's last breath) is "espirare".

However, there are also some animations that created problems.

I translated the French phrase: "Des fleurs rouge-sang tombent des tiges trop frêles, éclatent au fond de l'étang" as: "Fiori rosso sangue cadono steli troppo fragili, scoppiano nel fondo dello stagno."

In French the animation makes the letter/d/ move to "des fleurs", but in Italian I decided not to translate the article to give the phrase a more poetic sense, so in Italian the letter /d/ moves to "dello stagno" (to the article of the word pond) anticipating again the end. However, we agree with Alexandra Saemmer that this animation is even more poetic than the original French one. As she wrote me in a mail "the decision (which is the word before this sentence) is like this drowing in the pond".

Although French and Italian are both Latin languages, and often the structure of their phrasing is similar there are some major differences between these two languages. One of the most important differences is that in French one has always to express the subject of the phrase, while in Italian we tend not to do so.

In one section of the work six "je" (subjects) fall down in order to get to their position in the text (see picture below). But in Italian one cannot repeat the subject "io" for six times (especially when even the first time it is not required). The "je" (the subject pronoun) becomes "mi" and "me" (two object pronouns). In the French version - at the end of the section - all the "je" fall down again and become a single je: all the actions of the subject are summarized in one highlighted "je", that stays on the page also in the next section. In the Italian translation the "mi" and "me" become just "me". To be honest when I saw the animation I thought of transforming the two object pronouns into subject pronouns, transforming the "mi" and "me" into "io" but I wanted to keep the repetition of the first "me", which was the only way to maintain the repetition given by the "je". Of course it's not the 
same aesthetic value and it's not the same poetic result as well. The displacement of the "je" on the page, or better on the burned pictured is lost. The fragmentation of the "je" is lost. The Italian translation does not allow to have the same effect. Here something from the departure text is lost forever.
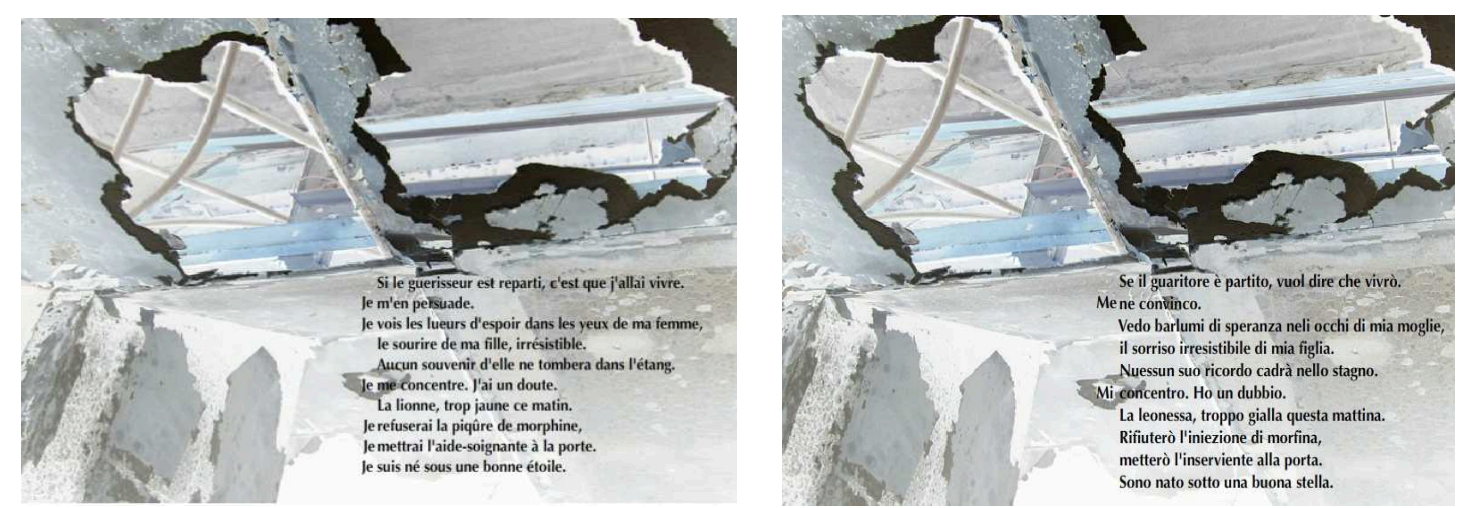

Fig. 6 and Fig. 7: Alexandra Saemmer, Etang - French and Italian version

The major problem in translating Etang by Saemmer was due to the difficulties in translating the same animation the words had in the original text, reproducing the same aesthetic effects. Sometimes fragments of text in the French version have more animated effects than the Italian version (as we have seen), sometimes the Italian text can be more redundant. For instance, in the French text the sentence "Il faut que je te résiste" ends with the verb "résiste" flashing, while in the Italian version the verb "resistere" is repeated twice in order to give the verb more strength and more hope.

Déprise by Serge Bouchardon (<http://www.sergebouchardon.com/>) presents others difficulties in translating electronic literature. The first difficulty I encountered in translating this text was a linguistic problem: how to translate the title "Déprise". "Déprise" in Italian means "abbandono". There is also (and there was already when I translated the text) an English translation of Déprise entitled: Loss of Grasp. So the word "déprise" is problematic for both languages. I decided to translate it with the reflexive verb "perdersi". "Perdersi" means "to get lost". Obviously, the meaning is different but if one is lost, she feels also abandoned and alone as well as other feelings somehow related to those suggested by the word "déprise". 


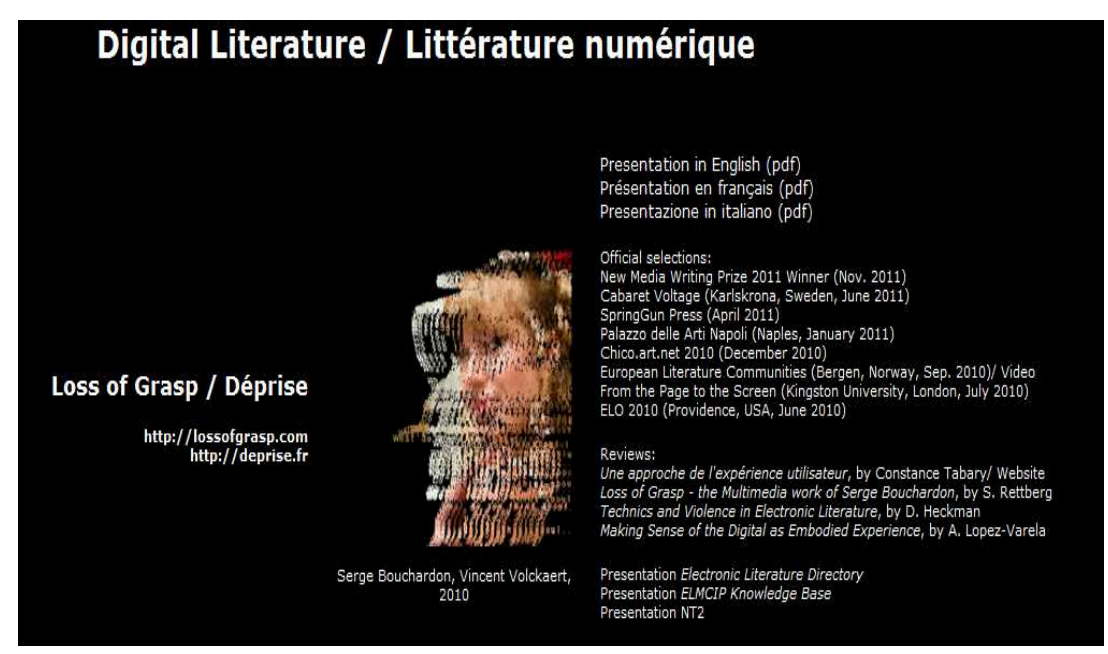

Fig. 8: Serge Bouchardon, Loss of Grasp

Besides the question on how to translate the title, so besides a proper linguistic problem that was the first I met, the text puts forward other characteristics that can be considered typical of this kind of texts.

Bouchardon describes Déprise as a work that:

recreates the loss of self-control. What happens when one has the impression of losing control in life, of losing control of his/her own life? Six scenes tell the story of a man that is losing himself. Loss of Grasp plays with the self-control and the loss of self-control and invites the reader to experiment with these feelings in an interactive work ${ }^{6}$.

Bouchardon talks about scenes, a word that is used more for movies than for texts, which has to be taken into consideration when translating this work. The approach to the text has to be different.

Another complicated part was what Bouchardon called the "alteration": in fact in one scene there are some sentences that will be changed:

\footnotetext{
${ }^{6}$ BOUCHARDON, S. Loss of Grasp. In: MASUCCI, L.; DI ROSARIO, G. (Eds). ELO: Officina di Letteratura Electronica. Napoli: Atelier Multimediale, 2011. p. 45.
} 
French

"Vous habitez la région depuis longtemps ?" alteration= "Vous évitez la légion depuis longtemps?"

"Et vous travaillez dans quoi ?" alteration= "Et vous travaillez l'envoi ?"

"Je vous trouve vraiment très jolie !" alteration= "Chevaux, brousse, bêlement... près jolis"

"J'ai l'impression qu'on a beaucoup de points communs" alteration= "Chemins pression en Allemagne point comme un..."

"Vous avez des yeux somptueux" alteration= "Vous avouez des notions de tueurs"

"Vous venez souvent ici ?" alteration= "Vous avez l'absent acquis"

"Puis-je vous offrir un autre verre ?" alteration= "Pigeon ouïr un Notre Père ?"

"J'ai votre façon de sourire" alteration= "Gêne, votre garçon mourir"

"Vous voulez marcher un peu ?" alteration= "Nouveaux-nés barges et il pleut."

Italian

"Abiti in questa regione da molto ?" alteration= "Eviti la legione da molto ?"

"E che lavoro fai ?" alteration= "E la posta la invii mai ?"

"Sei molto bella" alteration= "Cavalli, cespuglio. É una sella"

"Ho l'impressione che abbiamo molti punti in commune" alteration= "Mi fa impressione che in Germania non ci siano dune"

"Hai degli occhi deliziosi" alteration= "Hai dei modi rabbiosi"

"Qui ci vieni spesso ?" alteration= "Hai comprato il lesso"

"Un altro drink te lo posso offrire ?" alteration= "Un piccione il Padre Nostro sentire ?"

"Ho il tuo modo di sorridere" alteration= "Che fastidio, il tuo ragazzo uccidere"

"Ti va di camminare un po' ?" alteration= "I neonati sono svitati, piove no"

I left some of the meanings - especially in the main sentences - but I played with the sound of the words in the "alteration", like Bouchardon did in the French version so the meaning of some sentences is totally different.

Another interesting aspect of translating Déprise is that when I translated this work not only I translated the text but I also had to provide the Italian version for the background. Déprise in fact has also an audio. Besides the difficulties concerning the translation of the text I also need to find 3 people to recite the text and to have the instrument to record it. It was not so easy because one of the characters is a teenager boy, and I do not know many Italian teenagers. Eventually, the of one of my friends helped us. But as soon as we recorded the audio I realized that my 
friend's cousin had a very strong regional accent: while the other two voice were almost neutral, no particularly accent could be easily identified, the teenager had a strong accent of my city dialect "Aretino". What to do: looking for someone else or keeping him and his accent? At the end we decided that the strong accent could give even more "sense of reality" to the text. What Déprise was telling could happen everywhere and anywhere. The strong accent located it in a certain place very identifiable for Italian speakers.

The other aspect I would like to point out is the new instrument the translator of electronic literature needs to be familiar with in order to translate it. As well as the author of electronic literature needs to be familiar with the new digital writing "medium", also the translator has to learn and acquire - at least to a certain extent - these competences for both understanding what she is translating (or missing, as for instance in Alexandra Saemmer's Etang) and for practically translating it. The role of translator of translator in the digital era is changing: not only does she need to translate words, but also images and movements, and sometimes she is also required to have the technical competences to do it.

\section{Conclusion}

For all these different vertex of the variable geometry of translation, today we consider translation as an activity that has to do with ethics, aesthetics, politics and poetry. The translator maps traces of a readable interconnection: the interconnected readability. She searches the complex pathways through which the text travels. It produces a strange combination of presence-absence in the act of translation, because in the final text there's always something missing, somehow, from the original text. But at the same time, it still survives there, in its recreation. I think this is a fascinating textual journey that shows the interconnection of writing within the culture, the language and the world. "We read in order to know that we are not alone," thought Clarice Lispector. Similarly, we could say that we do translate to share the sense and the humanity, a pretty creative way of cannibalism. 


\section{Works Cited}

BOUCHARDON, Serge. Loss of Grasp. In: MASUCCI, L; DI ROSARIO, G. (Eds.), ELO: Oficina di Letteratura Electronica. Napoli: Atelier Multimediale, 2011. p. 45.

DERRIDA, Jacques. Differance. In: ADAMS, H; SEARLE, L. (Eds.) Critical Theory Since 1965. Tallahassee: Florida State University, p. 120-36.

DI ROSARIO, Giovanna. Electronic Poetry. Understanding. In: Poetry in the Digital Environment. Jyväskylä: Jyväskylä University Press, 2011.

FRAWLEY, William. Prolegomenon to a Theory of Translation. In: FRAWLEY, W. (Ed.) Translation: Literary,Linguistic, and Philosophical Perspectives. London \& Toronto: Associated University Presses, 1984, p. 159-175.

GLAZIER, Loss Pequeño. Digital Poetics: The Making of E-Poetries. Alabama: University of Alabama Press, 2001.

JAKOBSON, Roman. On Linguistic Aspects of Translation. In: BROWER, R. (Ed.), On Translation. Oxford: Oxford University Press, 1959, p. 232-239.

NIDA, Eugene. Toward a Science of Translating. Leiden: EJ. Brill, 1964.

RIFFATERRE, Michael. Transposing Presuppositions on the Semiotics of Literary Translation. In: Schulte, R; Biguenet, J. (Eds.). Theories of Translation. An Anthology of Essays from Dryden to Derrida. Chicago and London: University of Chicago Press, 1992. p. 204-217.

VENUTI, Lawrence. The Translator's Invisibility. London \& New York: Routledge, 1995.

Texto recebido em 19/06/2012 